\title{
Selling the American Way: The Singer Sales System in Japan, 1900-1938
}

\section{Citation}

Gordon, Andrew. Forthcoming. Selling the American way: The Singer Sales System in Japan, 1900-1938. Business History Review.

\section{Published Version}

http://www.hbs.edu/bhr/

\section{Permanent link}

http://nrs.harvard.edu/urn-3:HUL.InstRepos:2622951

\section{Terms of Use}

This article was downloaded from Harvard University's DASH repository, and is made available under the terms and conditions applicable to Other Posted Material, as set forth at http:// nrs.harvard.edu/urn-3:HUL.InstRepos:dash.current.terms-of-use\#LAA

\section{Share Your Story}

The Harvard community has made this article openly available.

Please share how this access benefits you. Submit a story.

Accessibility 


\title{
Andrew Gordon
}

\section{Selling the American Way: The Singer Sales System in Japan, 1900-1938}

\begin{abstract}
From 1900 through the 1920s, Singer put in place its proven selling system in Japan, despite making remarkably little adjustment to local conditions, and with a fair degree of success. But the company was hurt in the long run, with a turning point in the early- to mid-1930s, by its refusal to adapt-as its local competitors did-to the expectations of employees and the limited means of potential customers. Singer's dramatic rise and fall in Japan reveals ways in which practices of global capitalism are simultaneously transformed and transformative as they take root in particular locales.
\end{abstract}

$\mathrm{W}^{\mathrm{s}}$ hen the Singer Sewing Machine Company entered the Japanese market in earnest in 1900, it carried a half-century of experience as "the world's first successful multinational company." ${ }^{1}$ Founded in 1851 by Isaac Merrit Singer, the company focused on world markets and household users from the outset. By 1864, exports accounted for 40 percent of machines sold. By 1880, Singer claimed almost half of the world sewing-machine market (including nearly 40 percent of all sewing-machine sales outside the United States). Its worldwide sales that year surpassed 500,000 units. By the eve of World War I, shipping its product from factories in the United States (New Jersey), Scotland, and Russia, Singer controlled 60 percent of the American market in household machines and probably 90 percent of foreign markets. ${ }^{2}$

ANDREW GORDON is the Lee and Juliet Folger Fund Professor of History at Harvard University.

${ }^{1}$ Geoffrey G. Jones and David Kiron, "Singer Sewing Machine Company: 1851-1914," Harvard Business School case N9-804-001 (Boston, 2003), 1.

${ }^{2}$ On Singer's early history, see: Fred V. Carstensen, American Enterprise in Foreign Markets: Singer and International Harvester in Imperial Russia (Chapel Hill, 1984), 17-19, 24-25; Andrew Godley, "Selling the Sewing Machine Around the World: Singer's International Marketing Strategies, 1850-1920," Enterprise and Society 7 (June 2006): 270-76, 302; Robert Bruce Davies, Peacefully Working to Conquer the World: Singer Sewing Machines in Foreign Markets, 1852-1920 (New York, 1976), 161.

Business History Review 82 (Winter 2008): 671-699. (C) 2008 by The President and Fellows of Harvard College. 
Business historians have naturally been intrigued by this remarkable company. In explaining its success, they have reached a persuasive consensus. The company's unchallenged global position derived not from low cost, as its machines were relatively expensive. Nor was it grounded in technological superiority: other American and German machines were reputedly better. The secret was neither more appealing design than others, for all the leading machines looked alike, nor was it more effective advertising. The Singer magic lay in "its direct selling organization knocking on people's doors all around the world." 3

Singer was founded and headquartered in the United States. While having origins in America, the renowned selling system that it brought to Japan in 1900 had by then taken firm shape as a product of transAtlantic and transnational experience. The company drew on selling experience gained in Britain to devise its famous canvassing system. A number of German managers were sent to run Singer's early business in Russia. Against this background, it is no surprise that, in early twentiethcentury Japan, Singer proudly advertised the sewing machine as a good in the vanguard of global civilization, embraced by "Europeans and Americans ... of all classes high and low."4

As Singer set up its operation in Japan, it made remarkably little adjustment to its selling system. In less than a decade, Singer's shops had spread throughout the country, and Singer was able to operate its one-size-fits-all global model with fair success into the early 1930s. But tensions with employees and their expectations, a narrow focus on relatively affluent customers, and the slow pace of the spread of Western dress for women significantly limited this success. The company was hurt in the long run by its refusal to adapt-as its competitors did-to meet the expectations of employees and customers. Ironically, as Singer's selling system was effectively localized by competitors, the habits of the local sewing-machine users became globally uniform, for only with the spread of Western dress did the sewing machine find a mass market in Japan. A history of Singer's dramatic rise and fall in Japan thus offers insight into the ways in which practices of global capitalism are simultaneously transformed and transformative as they take root in particular locales.

Christopher Bayly, in his extraordinary recent work of global history, suggests something of the relevance of the sewing machine, and Japan, for such an inquiry into the dynamics of globalization. He places

\footnotetext{
${ }^{3}$ Godley, "Selling the Sewing Machine," 268-69.

${ }^{4}$ These phrases appear at the head of a Singer Japanese-language sales pamphlet. "Katei oyobi shokugyō yō shingaa mishin mokuroku" [Catalog of Singer Sewing Machines for Household and Industrial Use]. Held in collection of the Edo-Tokyo Museum, item \# 93200196, undated.
} 
prominently in his introduction a print of an elite Japanese woman pedaling a Singer machine to make the point that the adoption by elites of uniform Western wear was an emblematic step toward global modernity in the nineteenth century. We will see that similarly emblematic of a twentieth-century global modernity was the spread of Western dress to masses of ordinary men and then women. ${ }^{5}$

Bayly also follows Arjun Appadurai in arguing that central to the modern world's economic and cultural history has been a process in which the global and the local feed off each other. As Appadurai has argued, counter to a view of globalization as homogenization, "globalization is a deeply historical, uneven, even localizing process." He notes that "at least as rapidly as forces from various metropolises are brought into new societies they tend to become indigenized in one or another way." ${ }^{\prime 6}$ Here I explore one such process in the early twentieth-century history of globalization: the export and adaptation of the American way of selling in Japan.

\section{Singer Sets Up Shop}

When Japanese negotiators signed the "unequal treaties" with the Western powers in $1857-58$, they gave foreigners extraterritorial privileges in the treaty ports. But, in exchange, they won a prohibition against foreigners doing business, owning property, traveling, or residing outside designated ports and settlements. To import its selling system along with its machines, the Singer Sewing Machine Corporation had to be able to lease property for retail storefronts throughout Japan. Only upon revision of these treaties and the end to the so-called mixedresidence prohibitions, effective in 1899, was Singer able to do so. In short order, the company consolidated a position so strong in Japan that its brand name came to stand in-like Hoover, Kleenex, or Vaseline in other countries-for the product itself.

As it did around the world, Singer set up a three-tiered organizational pyramid under the purview of a national head office, which oversaw a small number of "central" offices in turn coordinating a network of regional or "branch" offices. Five or six regional offices were set up under each central office. The regional offices supervised the many retail stores selling directly to customers. ${ }^{7}$ The central and regional offices

\footnotetext{
${ }^{5}$ C. A. Bayly, The Birth of the Modern World, 1780-1914 (Oxford, 2004), 12-13.

${ }^{6}$ Ibid., 1-2; Arjun Appadurai, Modernity At Large: Cultural Dimensions of Globalization (Minneapolis, 1996), 17, 32.

${ }^{7}$ Kuwahara Tetsuya, "Shoki takokuseki kigyō no tainichi tōshi to minzoku kigyō" [Pioneering Multinationals Investment in Japan and Native Firms], Kokumin keizai zasshi 185 (May 2002): 52.
} 


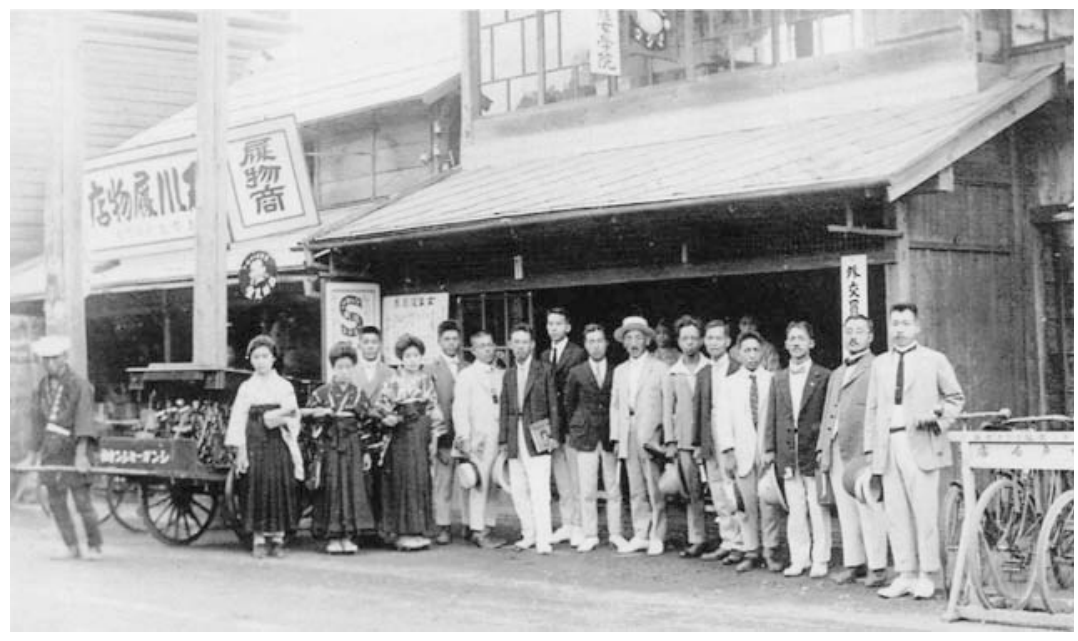

Salesmen and teachers employed by Singer outside the company's retail shop in the city of Mito, 1922. (Courtesy of Mochizuki Yoshimasa.)

were staffed by salaried employees who managed accounts along with inventory, distributed the product and parts, and oversaw the operations of the retail shops. These local shops comprised a manager and his staff of salesmen, installment collectors, instructors (usually young women), repairmen, and transport workers. The managers, sellers, and collectors worked on straight commission. The instructors were paid a weekly wage but were also expected-as a condition of continued employment -to drum up sales for which they received commissions. A photograph of employees in front of the Singer shop in the city of Mito, two hours by train north of Tokyo, illustrates this division of labor.

A valuable window into the thinking of Singer's Japanese managers in these early days is opened by a 1903 report filed by Hata Toshiyuki, an important figure in the company's history in Japan. Hata graduated from Tokyo Imperial University in 1899, and he entered the Ministry of Agriculture and Commerce, which sent him for a year of foreign study in the United States with instructions to visit the Singer Company and learn about its operations. Hata came away sufficiently enthused at "the potential for this company to contribute to commerce and friendship between the United States and Japan" that he decided to leave the Ministry in October 1903 for a managerial post in Singer's Japanese operation. In a report submitted to the Ministry before his resignation, Hata extolled the Singer organization for its cost efficiency. As he saw it, Singer was in the forefront of American manufacturers that had pio- 
neered ways to sell products directly to the public. Anticipating arguments that have been made for at least a century since that time, he explained that if large-scale producers in Japan could follow the Singer model and cut through layers of distributors, selling directly to customers, "they could provide the newest inventions to all people at the lowest prices." 8

Hata was correct to conclude that Singer had devised an effective sales system, but he was wrong to call it cost efficient. The numerous leased stores and the large salaried staff in the central and regional offices added up to a substantial fixed cost. Andrew Godley notes that, in the United States, "flooding the country with shops, canvassers, and collectors was a very expensive method of selling." a careful comparative and global analysis of the Singer selling system, concluding that its selling organization tended to "maximize sales rather than profits." ${ }^{10}$ In Japan as elsewhere, it succeeded for many decades, not because of low cost but despite relatively high cost. It did so by building an omnipresent network not only for selling its machines, but also for instructing buyers in their use and offering reliable maintenance and repair. ${ }^{11}$

Probably in order to be close to the unloading docks and customs house, Singer's corporate headquarters in Japan was initially established in Yokohama but was then moved to the port of Kobe in 1924, following the devastating Kanto earthquake of 1923, only to be moved back to Yokohama in 1933 following a bitter labor dispute. By the 1920s, Singer maintained four central offices, in Yokohama, Kobe, Osaka, and Seoul. The Kobe central office oversaw all regions to its west (including Taiwan), the Osaka operation superintended the regions of central Japan, and the Yokohama central office coordinated regional branches from Kanto to the north. The Seoul central office oversaw a growing operation in Korea and Manchuria.

After opening the first store in Tokyo in the summer of 1900, Singer built this network at an impressive pace. Actual lists of stores are fragmentary, but the trajectory is clear. Hata's report claimed that Singer had, by 1903, opened stores in eight cities: Yokohama, Tokyo (most likely several stores already), Osaka, Kobe, Nagoya, Nagasaki, Shizuoka,

\footnotetext{
${ }^{8}$ Hata Toshiyuki, "Shingaa seizō kaisha ni kan suru hōkoku” [Report on Singer Manufacturing Company] (1903), 2, held in Tokyo Chamber of Commerce archives. Reprinted in Matsumura Satoshi, Kaigai jitsugyō kenshūsei hōkoku, Nōshōmushō shōkōkyoku rinji hōkoku, vol. 10 (Tokyo, 2002), 326.

${ }^{9}$ Godley, "Selling the Sewing Machine," 282, draws on Walter A. Friedman, The Birth of the Salesman: The Transformation of Selling in America (Cambridge, Mass., 2004).

${ }^{10}$ Godley, "Selling the Sewing Machine," 291.

${ }^{11}$ Ibid., 296.
} 
and Maebashi. ${ }^{12}$ A typewritten global "Directory of Shops Under Controlling Agency," undated but most likely from 1904, lists fifty-one stores, and a 1906 directory reveals that Singer's Japanese network boasted seventy-one retail stores from Sapporo in the north to Kagoshima in the south (one per city, except Tokyo with eight). Japan at this time included the colony of Taiwan, where Singer had opened a single store in Taipei (Taihoku). Korea, in 1906 a Japanese protectorate but not in formal terms a full colony, was listed separately with three stores. ${ }^{13}$ Sales figures follow a similar upward trend, from 6,529 machines sold in 1903, the first year for which reliable data are available, to 12,895 in 1906 , to over 20,000 in 1911 . By the end of the 1920s, the company boasted a Japanese operation of roughly eight hundred stores and eight thousand employees.

At the heart of the Singer system stood the salesman, or canvasser. A retrospective account from 1951, most likely the testimony of a veteran Singer salesman, offers a neat summary of the canvasser's daily routine in the prewar era, as well as the strategies and support personnel that made him effective:

A sales office is set up, with a goal, say of 100 machines in monthly sales, and there are three levels of employee: an office chief, said to be a veteran with strong powers of observation, salesmen, and assistants. The salesmen go door-to-door in a given district in the morning, and record a set array of information on the customer prospects on cards. These cards are turned into the office at noon each day. The office chief then selects one or two good prospects. The salesmen are then sent to make second visits to these. When a few strong prospects are thus identified, the salesman and a teacher make a visit, with a machine in hand, and give a demonstration. Then they leave the machine for a free trial period, during which customers can get free lessons. By now, a sale is understood to be assured. ${ }^{14}$

This account touches on several key aspects of the Singer way of selling. These were not spot transactions: the salesmen were building long-term relationships. Success required keen understanding of the social world of their clientele, including an understanding among male sellers of the women customers' lives and desires that was not easy to come by. Yamamoto Tōsaku, a Singer salesman who would in 1932-33 lead the Singer employees in their dispute, recalled that most sales dur-

${ }^{12}$ Hata, "Shingaa seizō kaisha," 3.

13 "Directory of Shops under Controlling Agency" [1904?]; and "Directory of Shops for the Sale of Singer Sewing Machines throughout the World, revised Jan. 1906," both in the Singer Sewing Machine Company Archives held at the Wisconsin State Historical Society.

${ }^{14}$ Osaka tsūshō sangyō kyoku ed., Mishin kōgyō [The Sewing Machine Industry] (Osaka, 1951), 315. 
ing his time with the company (1917-33) were to well-to-do families. "First we would look into the entryway to see what sort of footwear there was, and maybe the daughter of the house is 3 or 4 years old, so we'd plan to come back in several years to try to make a sale." Yamamoto griped that "selling Singers was really hard. The buyers were women so it was particularly tough. At the time, they had no knowledge of machines, and it was the era of hand sewing, so it was really tough to sell them a Singer sewing machine." ${ }^{\text {15 }}$ Another discussant, Sekine Harukichi, recalled working one home for eight or even ten years. Yamamoto added, "To sell even one machine, you needed to butter up the cat, too. The cat wasn't stupid! If you kicked the cat, the deal was off!"16

For users who already owned sewing machines, Singer's aggressive trade-in policy, also part of its global system, was crucial. A latenineteenth-century American ad stated Singer's willingness to take in old machines, boasting that "such [imperfect competitor] machines ought to be put out of existence. We therefore offer to exchange our new and latest improved Machines for old Sewing Machines of every kind, on liberal terms. Such old Machines as are thus obtained by us will be destroyed." ${ }^{17}$ In Japan, this practice, together with an abundant inventory of parts, allowed the company literally to smash its competition, in particular the German makers who dominated the Japanese market before Singer began full-scale operations. Singer's early leaflets in Japan noted prominently its willingness to take old machines of any make for trade-in, and Yamamoto and other Singer veterans recalled taking in any and all German machines on trade-in and then simply destroying them in order to eliminate any source of spare parts or other secondary market for the competition..$^{18}$ Only a company with tremendous capital resources could afford this costly competitive strategy rather than reselling the machines.

The household machine and home-based users constituted the great majority of Singer's market in Japan. Selling to these homes was a team effort, designed to create demand for a product whose use was not yet well known. The free trials featured prominently in Singer advertising leaflets were crucial in this regard. Like the abundant parts inventory and the wasteful disposal of trade-ins, these trials made the Singer selling system expensive. A second retrospective account estimated, less

\footnotetext{
${ }^{15}$ Abe Tsugio, ed., Mishin konjaku monogatari [Long-Ago Tales of the Sewing Machine] (Tokyo, 1960), 28.

${ }^{16}$ Abe, Mishin konjaku monogatari, 29.

${ }^{17}$ Ad headlined "Singer's Sewing Machines," undated. The text notes that Singer quality "has just been confirmed" with a Gold Medal at the Great Exposition at the Palace of Industry, in France, placing it either shortly after the 1878 or the 1889 exposition. Smithsonian Institute Archives, Warshaw Collection, Sewing Machines, box 3, folder 1.

${ }^{18}$ Abe, Mishin konjaku monogatari, 28.
} 
optimistically but more believably than the 1951 recollection of Singer's prewar selling routine, that 20 percent to 30 percent of those who took in machines on trial actually purchased them. ${ }^{19}$ This was no just-in-time inventory system. Singer had to keep its retail stores stocked with an inventory several times larger than its monthly total of final sales.

A stylishly independent and modern figure in the group effort to educate users and create demand among those not familiar with the product was the "woman teacher" (onna kyōshi). Three of these young women can be seen standing proudly in front of the Mito shop in 1922 wearing skirts called hakama, which during the Tokugawa era (16031867) was a garment for men that had been appropriated as women's fashion in the late nineteenth century, first by schoolgirls and then by these working women. They often trained at the Singer Sewing Academy in Tokyo, which opened in 1906 with Hata Toshiyuki's talented wife, Rimuko, its first director. The teachers would offer instruction for a fee at smaller Singer sewing schools located on the second story of many of the retail stores around the country (the sign for the Mito school is visible at the top of the photograph). In addition, they would visit the homes of buyers to offer free lessons, the precise number pegged to the machine's cost.

The visits of these teachers were connected to what Singer's Japanese managers justifiably saw as the most important innovation in Singer's entire arsenal of sales practices: the offer of installment credit. The weekly or monthly "free" lessons provided a strong incentive to continue paying the installments to the collector, whose monthly visits provided yet a third point of personal contact between Singer and its customers, following the canvasser and the teacher. Hata Toshiyuki in 1903 accurately attributed Singer's global success in significant measure to the installment plan:

The installment sales method is as follows. In the case of anyone who wants to purchase a Singer machine in one of these locations [around the world], the company will accept a small partial payment at the time that it gives the machine to the customer, who will pay the remainder in small weekly or monthly payments over a period of several years, finally taking full legal possession of the machine when the payments have all been made. This is said to enable those with limited resources to buy machines and use them. ${ }^{20}$

That Hata felt compelled to offer this belabored account of installment buying indicates that the practice was not well known in Japan at the

\footnotetext{
19 "Mishin gyōkai to seerusuman no kimyō na kankei” [The Strange Relationship of Salesmen to the Sewing Machine Industry], Nihon shūhō (15 Apr. 1964): 38.

${ }^{20}$ Hata, "Shingaa seizō kaisha," 5.
} 
time, as does his use of a rather unconventional term ( fukin) for installment selling, suggesting that no fixed vocabulary had settled into ordinary use.

At the time of Hata's writing, seasonal credit and various systems of revolving mutual-aid credit (called $k \bar{o}$ ) had a long history in rural society, and merchants in cities would typically allow known customers to carry open-book credit settled monthly or yearly. But modern consumer credit, defined as a practice whereby the borrower (or her husband) earned a weekly or monthly wage enabling formally contracted, regular installment payments, had only recently emerged. In the 1880 os and 1890 indigenous sellers in the lacquer industry, who for decades had peddled their ware on credit to rural households, shifted from seasonal or open-book to installment credit. ${ }^{21}$ These businesses evolved into "installment department stores" selling additional household goods, such as furniture, bedding, tatami, and clothing. ${ }^{22}$ Like the "borax stores" that spread in the United States from the 1880s, these sellers appealed to a relatively impoverished customer base with shoddy products. ${ }^{23}$

Around 1900, foreign corporations, including National Cash Register and the Encyclopedia Britannica, began to offer installment credit as well. Of these, Singer was by far the best known and most creative user of installment credit, spreading the practice of installment buying to a new clientele: middle- to upper-class urban families, women in particular. Unlike the native installment sellers, Singer used detailed written contracts; allowed a longer period for repayment; set the cost of goods high; and charged a modest credit premium. A Singer machine selling for 112-yen cash in 1924 cost a total of 140 yen on a two-year installment plan, a roughly 12 percent annual interest rate; installment department stores charged roughly 20 percent annual interest for their goods. ${ }^{24}$ Such a machine represented about two months' wages for an ordinary salaried male household head (this ratio held roughly constant from 1900 through the mid-1950s), and installment sales were a central element in Singer's rise to domination of the home market.

The company waited until 1907, seven years after its full-scale entry into the Japanese market, to begin to offer installment credit. The reason for this delay is not clear. Perhaps Singer not only wanted to accumulate sufficient funds in its Japanese headquarters and consolidate a sufficiently widespread network of stores, but also saw a need to cultivate a

\footnotetext{
${ }^{21}$ See Geppu kenkyū 1, no. 1 (15 Apr. 1957): 3; 1, no. 3 (15 June 1957): 3.

${ }^{22}$ Tokyo shōkō kaigishō, Geppu hanbai seido [The System of Installment Sales] (Tokyo, 1929), 212-13.

${ }^{23}$ Lendol Calder, Financing the American Dream (Princeton, 1999), 56-57.

${ }^{24}$ On installment department-store rates, Kuribayashi Sho, "Geppu no hanashi" [Story of Monthly Installments], Sarariiman 2 (Mar. 1929): 65-66.
} 


\section{Andrew Gordon / 680}

sufficiently disciplined sales force. Canvassers had to be trusted or taught not to offer contracts to buyers likely to default or, worse yet, abscond with the machine. Collectors had to be engaged who would reliably turn over the proceeds of their daily rounds.

Although we will see that Singer's control of the hearts and minds of its sellers in Japan was always tenuous, installment sales proved popular from the outset. The company's global sales reports show that "open accounts" (machines bought on credit) amounted to nearly 60 percent of all sales from 1909 to $1913 .{ }^{25}$ Delinquency was never a major problem, but the fragmentary evidence available in these annual reports reveals an increase over time in the reliability of Singer customers. From 1909 to 1913, anywhere from 4 percent to 12 percent of accounts in Japan were recorded as either "one to three" or "three or more" months' delinquent, although delinquency over three months never exceeded 1 percent and was in most years under .5 percent. The only subsequent year for which partly comparable data can be found is 1928. At this point, installment sales accounted for about 63 percent of total Japanese sales, and even short-term (one- to three-month) delinquent accounts were less than 1 percent of all open accounts. Longer-term delinquency was not reported, probably because it was considered negligible. Over time, then, Singer's customers had become more disciplined in their use of credit, and/or the canvassers grew more careful about whom they sold to. Indeed, we will see that Singer arguably became too cautious, as domestic competitors improvised new forms of credit that allowed them to find a market among less affluent, somewhat riskier customers.

Singer presented installment credit to Japanese customers not only as convenient, but also as a way to take part in a happy modern march of progress. A leaflet from about 1912 offers a typical such invocation:

The past quarter century has seen all sorts of impressive progress in Japan. . . . [In every country] the sewing machine has completely revolutionized the household economy. ... . Singer Sewing Machine Company's monthly installment method makes it possible for any sort of family to purchase this great economic good. The Singer Model 28 Hand Turned Machine can be purchased for the incredibly cheap price of 3 yen per month, for 16 months, in other words 10 sen a day. In this way you can make a useful lifelong investment. ${ }^{26}$

Singer here neatly linked the purchase of its machine, on credit, to the virtues of national pride and progress, as well as individual econ-

\footnotetext{
25 “Annual World Reports" held at Singer Sewing Machine Company archives, Wisconsin State Historical Society, Madison, Wisconsin.

${ }^{26}$ Singer sales leaflet, undated (approximately 1912), held in collection of Edo-Tokyo Museum.
} 
omy and investment. In later years, hugely popular monthly women's magazines echoed this view. ${ }^{27}$ In January 1920, one female columnist proclaimed, "All Daily Clothes for Children Should Be Western":

First, one must increase the efficiency of the housewife or servant by boldly switching over to Western clothes for children. To this end, one must furnish the home with a sewing machine. As this is in recent years possible for a small monthly installment payment, it is not that difficult for an ordinary family. ${ }^{28}$

Such articles framed buying on time in positive terms as an element in a modern life of discipline, economy, and investment. In addition, Singer advertising of the 1920 s appealed to a second face of modernity: the pursuit of freedom and pleasure. In one brochure, a sewing machine bought on time promised women the enjoyment of fashion and "the tremendous freedom of movement of Western dress." ${ }^{29}$ With its machines and its offers of "easy monthly payments," Singer was exporting a protean vision of modernity, both prudential and pleasing, in Japan as around the world. ${ }^{30}$

Over the several decades before Singer began its Japanese sales in earnest, every element of the Singer system here described had been put into practice in markets around the globe. Fred Carstensen's study of Singer in Russia, where the company enjoyed far greater success than it had in Japan in the early twentieth century, allows us to compare the two selling systems, both to each other and to the "original" Singer system as developed mainly in the United States, Britain, and Western Europe. In Russia, the huge distances between customers made it impractical to send canvassers and collectors separately to make their rounds, and the two functions of canvasser and collector were merged into a single job. In a related step, to make sure these sellers/collectors did not ignore existing accounts in favor of new ones, Singer reversed its

\footnotetext{
${ }^{27}$ The monthly circulation of Fujokai [Women's World] had reached nearly 200,000 copies by the early 1920s. "A Ten Year History," Fujokai 27 (Jan. 1923), offers circulation figures.

${ }^{28}$ Imura Nobuko, "Kodomo no nichijô fuku wo zenbu yôfuku ni" [Make All Children's Daily Dress Western Dress] Fujokai 21 (Jan. 1920): 213-15.

${ }^{29}$ Singer sales leaflet, approximately 1922, held in collection of Edo-Tokyo Museum.

${ }^{30}$ On the importance of credit for Singer's success in the United States, and its pioneering role in spreading installment sales to ordinary families, see Calder, Financing the American Dream, 162-66; and Friedman, Birth of A Salesman, 94-97. For a nice presentation of a similar dual appeal to customers in France, see Judith G. Coffin, "Credit, Consumption, and Images of Women's Desires: Selling the Sewing Machine in Late Nineteenth Century France," French Historical Studies 18 (Spring 1994): 749-83.
} 
ordinary practice and offered larger commissions for successful collection than for initial sales, and, in the face of labor unrest, Singer made other adjustments to its wage system. ${ }^{31}$

In Japan, in contrast, during its first decades of operation Singer made only one change to its imported sales system, a quite modest practical adjustment to local practice. Because wages for white-collar workers were issued monthly in Japan, rather than weekly as in many countries, the company structured its installment payment plan in monthly, rather than weekly, terms. For thirty years, Singer operated in Japan by selling an unaltered imported product with an unaltered imported sales system. To this extent, Singer's "globalization," contra Appadurai, appears to be a classic case of homogenization. But developments over the interwar decades reveal a more complicated and interesting story.

\section{Singer's Japanese Balance Sheet}

We begin to see the outlines of the story by examining the successes and limitations of the Singer sales system in placing the sewing machine in Japanese homes, first by drawing on a consolidated profile of Singer's Japanese results, prepared by the company immediately after World War II as part of the effort to document its "War Losses" and stake a claim to reparations (Figure 1$).^{32}$ Singer's household machine sales ranged from fifty thousand to eighty thousand units annually by the 1920s, and they underwent considerable variation from year to year. Unfortunately, no sources survive to explain how Singer or other observers understood this variation, but most of it follows logically from macroeconomic trends. The spike during World War I and immediately thereafter tracks the extraordinary wartime boom in Japan. The sharp drop in 1920-21 reflects the postwar recession. The spike in 1924 to the highest level of any year probably includes thousands of customers in the Tokyo Yokohama region replacing machines destroyed in the devastating earthquake of 1923 during the post-quake "reconstruction boom." The dismal results of 1930 through 1933 track the world depression as well as the strike that disrupted operations from the summer of 1932 through January 1933, and the gains of the following yearsthough we will see they could have been greater-reflect Japan's early recovery from the depression.

How profitable was this operation? According to Carstensen, the company goal in the early twentieth century, at least for Russia but it

\footnotetext{
${ }^{31}$ Carstensen, American Enterprise in Foreign Markets, 58.

${ }^{32}$ In preparing Figure 1, I have excluded machines sold by Singer's Manufacturing Trade Division (MTD), about 10 percent of the total, which were purchased by garment factories and other industrial producers (shoes, Japanese tabi socks).
} 


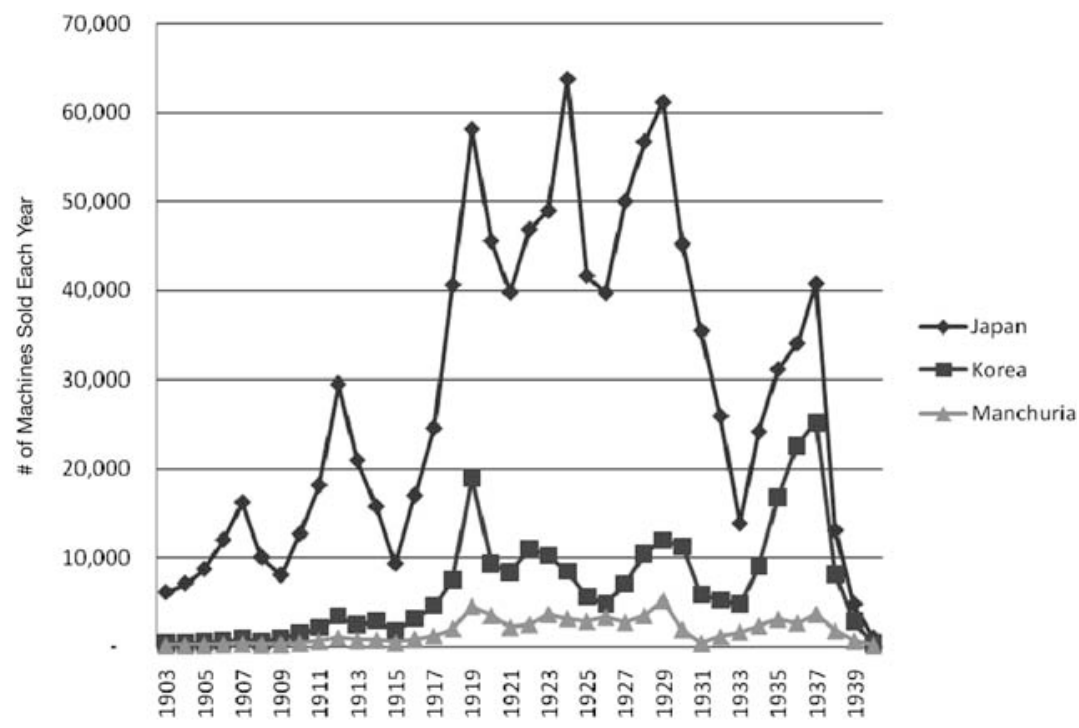

Figure 1. Singer's sales in northeast Asia, 1903-1939. (Source: Japan War Loss Records, box 148, folder 5, Singer Sewing Machine Archives at Wisconsin State Historical Society.)

would seem globally as well, was to keep the sum of in-country costsstore and office rents, commissions and wages, plus regional and central costs such as warehousing and advertising-below 45 percent of sales revenue. ${ }^{33}$ The remainder was needed to cover manufacturing and shipping, as well as corporate-headquarter costs and profits. Singer's annual world reports calculated total sales revenues and total expenses for each country (or colony) in which Singer operated. In many years, the preparers of this statement themselves divided each national or regional expense total into the revenue total, listing the percentage in a separate column, and in years where this number is not listed, we can do the division ourselves. (See Figure 2.)

It took some time for Singer to bring its Japanese operation up to its global standard. In its first two decades of full-scale operation in Japan, Singer consistently failed to keep expenses to 45 percent of sales. But from 1921 until the eve of total war, with the exception of the worst years of local and world depression from the late 1920 s through the early 1930 s, Singer's Japanese operation generally produced results in line with these worldwide expectations. Whether this mixed picture is viewed as successful or not depends on the point of reference. Carstensen notes of Russia that the 45 percent standard "was tough to meet."

\footnotetext{
${ }^{33}$ Carstensen, American Enterprise in Foreign Markets, 62-64.
} 


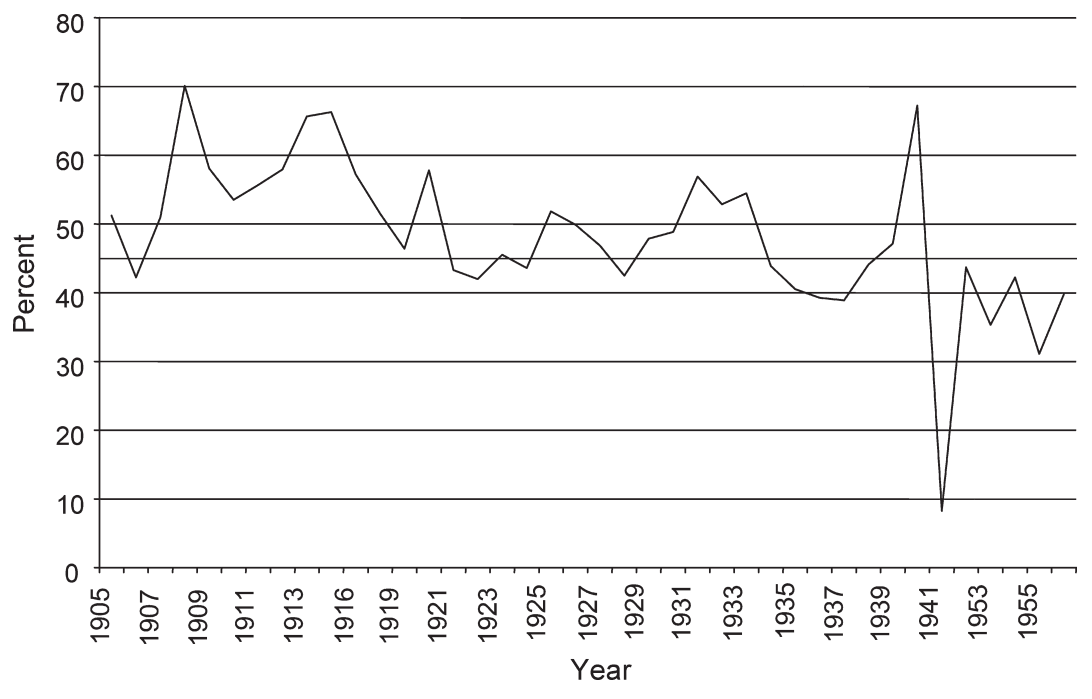

Figure 2. Ratio of Singer expenses to sales revenue in Japan. (Source: Singer Annual World Results, 1905-55, Singer Sewing Machine Archives at Wisconsin State Historical Society.)

Singer began direct-sales operations there in the 1880 s, but "only after 1908 did Kompaniya Singer regularly approach or exceed" this threshold. ${ }^{34}$ Similarly, Godley's comparative analysis of Singer's global sales results shows that the company rarely met this goal over the entire span from 1881 through 1914: "over the period as a whole the costs of selling accounted for 58 percent of income." 35 By this comparative measure, the tried-and-tested Singer system worked as well in Japan as elsewhere.

But, as Godley shows, the Singer system was built to maximize gross sales and market penetration more than profits, and by these measures the company could have done better in Japan. From 1903 through 1935 (the first year in which a substantial number of machines were sold by Japanese makers), Singer sold roughly 950,00o household-type machines in the Japanese home islands. With an estimated 13.5 million households in Japan as the denominator, simple division yields a 7.5 percent household penetration rate. This calculation does not account for attrition, which is not knowable but was certainly small, given the extraordinary durability of these machines. Calculated not by household but as sewing machines per capita to align the data with Godley's analysis, which likewise does not account for attrition, cumulative sales, at

\footnotetext{
${ }^{34}$ Ibid., 64.

${ }^{35}$ Godley, "Selling the Sewing Machine," 290.
} 
roughly ten machines per thousand in the population (1 percent) by 1924 and fifteen machines per thousand by 1935, lagged significantly behind diffusion rates in the Philippines, South Africa, the Balkans, and the Ottoman Empire. Singer's machines in the Ottoman region approached fourteen per thousand people by the start of World War I, two decades before reaching this level in Japan, despite the fact that per capita income in Japan in 1914 exceeded that of the Ottoman Empire. ${ }^{36}$

In sum, although Singer's operations in prewar Japan were reasonably effective in controlling costs and returning profits, the company through the mid-1930s did not place an impressive number of machines into the hands of users compared to other medium- to late-developing markets outside the advanced core of the world economy. And when a strong economy combined with new trends in women's dress to boost sales of household machines in the second half of the 1930s, it was the emerging Japanese sewing-machine producers who proved better able to capture this growing market by adapting the Singer system to meet employee expectations and customer needs.

\section{Adapting the Singer Model}

In his excellent book on the making of the American salesman, Walter Friedman shows that the sellers of the Singer machine played a key role in bringing system and reputability to a job whose earliest practitioners were notorious for lacking both. ${ }^{37} \mathrm{He}$ locates the transformation in the 188 os through the early 1900 , when a shift took place from a world of the "agricultural canvasser and the wholesale drummer" to "a newer, more aggressive, and highly managed form of salesmanship." At the forefront of this transformation were mass manufacturers who "began to build their own cadres of salesmen, and in doing so, developed the first modern sales forces ... [,] set[ting] the pattern for companies in the decades that followed." 38

Central to the endeavors of Singer and other large American corporations who gave birth to the modern salesman was the application of standardized systems to what came to be considered the science of selling, in a process parallel to the more famous revolution in "scientific management" pioneered by Frederick W. Taylor. ${ }^{39}$ Friedman begins his

\footnotetext{
${ }^{36}$ Andrew Godley, "Consumer Durables and Westernization in the Middle East: The Diffusion of Singer Sewing Machines in the Ottoman Region, 1880-1930," paper presented at Eighth Mediterranean Social and Political Research Meeting, Florence, Mar. 2007, 5-13. Comparative per capita income from Angus Maddison, The World Economy: Historical Statistics (Paris, 2003).

${ }^{37}$ Friedman, Birth of a Salesman.

${ }^{38}$ Ibid., 88.

${ }^{39}$ Ibid., 91.
} 
analysis of "scientific sales management" in America (and Britain) with Singer and the sewing machine, claiming persuasively that "the sale of the sewing machine paved the way for other expensive or intricate machines" from the vacuum cleaner to the automobile, whose makers in the early twentieth century also relied on door-to-door sellers providing information, education, and credit as they struggled to convince customers that the large cost of such a good was justified..$^{40}$

In Japan, as elsewhere, Singer was a leader in the "science" of systematic selling. The company advised salesmen on the protocols of comportment and dress and offered informal lessons in communication and psychology. But with Singer among the midwives, the birth of the salesman in Japan-not unlike the making of its working class-was a painful process, marked by considerable tension and resistance to the imposition of managerial discipline. Among the salesmen in the belly of the beast of modern capitalism-prominently including the Singer sales force-one finds crucial ambivalence in response to the logic of the market, especially to what was understood as an American way of doing business, and Singer proved unable to respond effectively.

The terms of the Singer salesman's trade in Japan, as elsewhere, were rather difficult. Canvassers earned a 12 percent commission on each machine sold. The first 10 percent was paid on the signing of the sales contract and receipt of the down payment. The remaining 2 percent was paid to the seller over three months, starting when the first monthly installment was paid to the collector and pending the successful continuing collection of installments. The Singer collectors earned a 7 percent commission, likewise pegged to their successful yield from customers. Few records survive that document individual canvassers' income in Japan, but a rough calculation from the aggregate figures makes it clear that many of the sellers and collectors must have taken home relatively thin pay envelopes. In the late 1920s, a time when the company employed a total of seven thousand to eight thousand people, including salaried office staff and teachers, as well as sellers, canvassers, and branch managers paid by result, annual expenses stood at $\$ 3$ million per year maximum, roughly $\$ 450$ per employee. Even if the company's local expenses had consisted almost entirely of wages, at the exchange rate of two yen per dollar, the average income would have been under eighty yen per month, roughly the entry-level pay of a male white-collar worker at the time. But of course the "expenses" category-although unfortunately not broken down-included rent, transport and warehouse costs, advertising, and utilities, so the net average income of Singer employees was well under the earnings of the typical salaried office employee 
of the era. The 1932-33 strike provoked one employee to enumerate in detail his income and expenses in a leaflet. His particular figures roughly square with this aggregate calculation if we assume that about half of the overall operating expenses went to wages: this Tokyo-based payment collector, working on commission, took home a net monthly income of forty-six yen..$^{41}$

Given these figures, it is no surprise that turnover was high. The world of the sellers was divided into a small group made up of those who thrived and excelled, such as the passionate Yamamoto Tōsaku, who rose within two years to become manager of the most successful local store in the nation, and a large group whose members entered and exited quickly. ${ }^{42}$ The photo of Singer's Mito shop displays a signboard proclaiming "Salesmen Wanted," visual evidence of the chronic need for new troops to carry the Singer message door to door. The protesting employees in 1932 argued that punitive terms of employment were the cause of high turnover, offering as evidence a Yokohama store that employed thirty-one different salesmen in the course of a year in order to main a staff of nine canvassers. ${ }^{43}$

For these Singer sellers, discontent was not limited to low pay. Even the successful sellers were frustrated by the uncertainty of their employment and by what they considered unfair disciplinary practices: the high-flying Yamamoto, after all, was a leader of the Singer dispute group. The "fidelity insurance plan" used globally by Singer to keep salesmen honest and protect the company from losses generated strong criticism. It imposed annual premiums of five to ten yen on Singer canvassers and collectors and would cover from five hundred to one thousand yen of losses if, for example, a customer absconded with a machine before completing installment payments. Singer added additional layers of protection by making the sellers in the first instance responsible through pay deductions for losses generated by customers, by further having each seller place two hundred yen on deposit with the company from which penalty charges could be drawn, and by requiring these men to list two guarantors who were also responsible for any of these losses.

The employees in 1932 argued that the company profited hugely from this multilayered system of protection; they questioned whether

\footnotetext{
${ }^{41}$ Koyama Okazaemon, "Watakushi no itsuwarazaru kokuhaku" [My True Confession] in Gaimushō kiroku, "Honpō ni okeru rōdō sōgi kankei zakken: Shingaa kaisha kankei," [Documents Concerning Labor Disputes in Our Country: Singer Company], 449-56.

${ }^{42}$ Shimozono Satoshi, Dotō o koete: Yamamoto Tōsaku denki (1960), 52-53. This hagiographic biography may well exaggerate his ranking, but Yamamoto was without doubt a successful salesman.

${ }^{43}$ Matsuoka Komakichi, "Shingaa kaisha sōgi no keika to sono shinsō" [The Truth About the Singer Company Dispute], 15 Dec. 1932, in Gaimushō kiroku, 590.
} 
the fidelity insurance premiums were actually turned over to an insurance company and demanded the issue of insurance certificates to each employee. The salesmen also complained bitterly and chronically over the assessments levied on sellers, canvassers, or store managers and deducted from their pay. Not only did these assessments extend to cases of customers absconding with machines not paid for; they also applied to premature termination of an installment contract, on the one hand, or completion of payments on the principal balance ahead of time at a cash discount, on the other. Singer deducted from the sellers' and collectors' wages the portion of the commission that, by Singer's logic, had been prepaid in anticipation of installment revenues now lost. ${ }^{44}$

Discontent with these policies led Singer employees to launch two small labor disputes in the mid-1920s: one in Tokyo in March 1925; another, led by employees in Osaka area stores, lasting from December 1925 through January 1926; and a major struggle that continued from September 1932 through January $1933 .{ }^{45}$ By the time of the 1932-33 action, the employee association was bitter enough to characterize itself as heirs to a "thirty year history" of enmity with the company, claiming that nearly thirty disputes, large and small, had taken place over conditions of employment since the company had been operating in Japan. ${ }^{46}$

As these discontents simmered and sometimes boiled over, Singer's top managers, who in the 1920 s included several Americans, one British man, and one Canadian, sought both to impose more effective discipline and to calm the situation by insisting to employees that their treatment was reasonable, that the seller's vocation both served society and offered realistic prospects of reward for hard work, and that, in any case, the globally tried-and-true Singer system could not possibly be changed. Documents generated during the dispute of 1932-33 offer the clearest statements of their position.

A lengthy "statement" given by Singer to the Japanese Foreign Ministry in November 1932 made the case that "our business in Japan, in addition to having given profitable employment to many thousands of men and women," has made "machine sewing an essential part of a girl's educational training," enabling girls to "form new homes" and sustaining the "future motherhood of the nation." 47 As the New Year holiday came to an end in early January 1933, shortly before the dispute was

44 "Yōkyūsho" [Demands] Gaimushō kiroku, 430-37.

${ }^{45}$ For documentation of both these disputes, see Kyū kyōchōkai shiryō rōdō sōgi, vol. 9 (1925), held at the Ohara Institute for Social Research.

${ }^{46}$ Shingaa kaisha sōgi ni kan suru ken [Issues regarding the Singer Company Dispute], 18 Nov. 1932, Gaimushō kiroku, 322-23.

47 "Statement" to "Mr. T. Taketomi, in charge of Foreign Trade, Foreign Office," Gaimushō kiroku, 249 (original in English). 
finally resolved in the company's favor, E. L. Vest, director of the Osaka Central Office, sent a long letter to the two hundred store managers in his jurisdiction urging them to continue this mission. The economic outlook had improved, he claimed, and many families long desiring to buy sewing machines for the sake of their children's education would be able to do so. To reach these customers, he claimed, "energetic door-todoor selling is indispensable," and, he continued, "there is no better method than setting out orderly blocks [of sales territory] from early in the new year. ... The salesmen must of course cover their blocks every day systematically and in proper order, and as we all know, one day's sales bring more the next day." 48

The many "how-to" books published in the interwar era aimed at salesmen (and some saleswomen) show that Singer was typical in invoking system and social progress in this fashion, in order to cultivate a proper selling mentality and behavior. One early work of this genre, dated 1916, was titled Scientific Business Strategies: Salesmen and Selling Tactics, a name that would seem to evoke Taylor's Principles of Scientific Management, translated three years earlier into Japanese. ${ }^{49}$ There is little to distinguish this book or later titles from the persuasive and educational tracts aimed at sellers in the United States, and they freely drew on American sources and anecdotes. Their advice echoed the Singer position that the system of selling in Japan faced no need to adapt to the particularities of the local scene. These works typically distinguished between the older, unsavory, and unsystematic selling practices of the itinerant peddler and the newer, honest, and respectable, scientific endeavors to advance a project of civilization and progress. Scientific Business Strategies, for example, began with a chapter on "the mission of the salesman," who is "the publicist for the happy sound of civilization." ${ }^{\circ} \mathrm{He}$ convinces people to "replace carts with bicycles, pencils with typewriters, (oil) lamps with electric lights, and needles with sewing machines." None of these modern goods, in this author's telling, were of obvious value or utility to the "extremely ignorant" ordinary folk of the world; without the persuasive power of the salesman, society would not march to the tune of progress. Twenty years later, Kuramoto Chōji echoed this theme, claiming that without the efforts of salesmen, "who create the desire for civilization," early users (in the

48 “Vest yori no kanyūjō," [A letter from Vest”], 11 Jan. 1933, Gaimushō kiroku, 875-76.

${ }^{49}$ Yoda Shintarō, Gakuriteki shōryaku hō: hanbaiin to hanbaijustu (Tokyo, 1916). Taylor's Principles were introduced in the popular press in Japan almost immediately upon publication in 1911, and the book was published in a full translation in 1913. See William Tsutsui, Manufacturing Ideology: Scientific Management in Twentieth Century Japan (Princeton, 1998), 18-19.

${ }^{50}$ Yoda, Gakuriteki shōryaku hō, 5 . 
United States) had been unwilling to try goods, such as sewing machines, whose utility eventually came to seem so obvious. ${ }^{51}$

Reading through these tracts, one senses in the repetition a frustration that core messages were not being heeded. Ishikawa Rokurō in 1925 argued that although people generally scorned the salesman, in an era of insecurity for the salary man at large the professional seller's work deserved respect. ${ }^{52}$ Shimizu Masami, the most prolific producer of "howto-sell" tracts, similarly claimed in 1925 that whereas "the old peddler has no trust or respect[,] . . . the new salesman has trust as his cornerstone"; and his expanded edition of 1937 essentially repeated his case..$^{53}$ In prewar Japan, it was an uphill battle to convince both sellers and their customers that theirs was an honorable profession on a par with the work of salaried managers running the prestigious offices of corporations or state bureaucracies. Only in later decades (and never completely, of course), parallel to their efforts to systematize employment relations for salaried and wage workers in office and factory, did many companies more effectively cultivate esprit and discipline among sellers, who more readily than before accepted the terms of their employment as natural and respectable.

In the sewing-machine industry over the long run, it was not Singer but its competitors who cultivated this sort of committed sales force. The turning point was the strike of 1932-33. In response to a precipitous fall in the value of the yen of 50 percent versus both dollar and pound from December 1931 through August 1932, Singer raised its prices by 25 percent, which it described as a restrained but needed step. ${ }^{54}$ In a domestic context of high unemployment and falling wages, sales plummeted (see Figure 1). This was the immediate cause of the dispute, which brought to the surface once more the longstanding grievances of Singer sellers, addressed in their three principal demands.

In addition to calling for a rollback in the price of Singer machines, the employees demanded a four-part "revision of the employment contract," reflecting their discontent at the array of pay deductions taken when installment payments were not collected as expected. ${ }^{55}$ The Singer shop managers and sellers in 1932 did not see exchange-rate fluctuations as a legitimate reason to raise prices, and they blasted as unfair

\footnotetext{
${ }^{51}$ Kuramoto Chōji, Atarashii gaikōjutsu [New Selling Tactics] (Tokyo, 1936), 14-15, 17.

${ }^{52}$ Ishikawa Rokuro, Shusse gaikōjutsu [Selling Tactics for Success] (Tokyo, 1925), 6-7.

${ }^{53}$ Shimizu Masami, Hōmon hanbai chūmon o toru hiketsu [Secrets of Success in Doorto-Door Sales] (Tokyo, 1924), 1-6.

${ }^{54}$ On the disastrous policies of Japan's 1929 return to, and 1931 move off, the gold standard, which led to this depreciation in the yen, see Mark Metzler, Lever of Empire: The International Gold Standard and the Crisis of Liberalism in Prewar Japan (Berkeley, 2006) chs. 10-12.

55 “Yōkyūsho,"Gaimushō kiroku, 429.
} 
the "adjustments" designed to link their commissions to actual (rather than pledged) payments by customers. These views were deeply and sincerely felt manifestations of the "moral economy" of the times in Japan that might well have been mobilized against a Japanese company with similar policies.

But with an additional demand for "the immediate establishment of a retirement and severance pay system," employees made clear their hostility toward what they saw as a specifically "American" capitalism. In this demand, they accepted the logic of a capitalism in which businesses sometimes failed and the employees were laid off, but they nonetheless put forward a view of legitimate "Japanese" employment practices, which were sharply at odds with the Singer system. By the 1920s, the majority of large Japanese firms were offering severance or retirement payments to employees proportional to length of employment. The government in 1926 had taken a small but meaningful step to codify this practice, when the Revised Factory Law (originally enacted in 1911) took effect with a provision that employers in most cases offer at least two weeks' notice, or two weeks' severance pay, to a dismissed employee..$^{6}$ In 1936 the Imperial Diet would write into law the requirement that all businesses with over fifty employees offer severance or retirement pay linked to years on the job. ${ }^{57}$ Thus, the employees in 1932 had grounds for maintaining that "although one does not find this system in America, we think it is natural that a company doing business in Japan, opening stores in Japan, employing Japanese people, and operating in accord with Japanese law, should set up the same system of the many companies in Japan." 58

The employees pursued these demands with a tactic more threatening to Singer than a strike, what one major daily called "a strange battle of endurance: collections and machines as weapons, conducting sales during the sewing machine dispute." As in the 1925 disputes, but with greater scope and for a longer time, employees took control of a significant portion of the Singer stores, inventory, and installment accounts. Store managers, canvassers, and collectors continued to go door to door selling machines and collecting installments, holding the proceeds "in trust" in bank accounts controlled by the employee association. In Tokyo alone, the forty-two shops joining the action were reported by Yomiuri to control an inventory of fifteen hundred machines worth over three hundred thousand yen at retail prices, and to control

\footnotetext{
${ }^{56}$ Kyōchōkai, ed., Saikin no shakai undō [Recent Social Movements] (Tokyo, 1927), 776.

${ }^{57}$ Andrew Gordon, "Business and the Corporate State: The Business Lobby and Bureaucrats on Labor, 1911-1941," in Managing Industrial Enterprise, ed. William Wray (Cambridge, Mass, 1989), 67-68.

58 "Yōkyūsho," Gaimushō kiroku, 429.
} 
an even more valuable ten thousand installment accounts with outstanding balances totaling over one million yen (about \$250,000). 59

Despite the clear damage its business was suffering, and despite the hands-off stance of Japanese authorities, who refused to declare these tactics illegal, Singer adamantly refused to make any concessions. The Western managers in Japan, with the support of the New York headquarters, justified their stance with a consistent chorus of claims for the universal nature of the Singer system over time and across the globe. A lengthy English-language document submitted to the Foreign Ministry and distributed in Japanese translation to employees and the press made the following points:

Every person who enters our organization comes in knowing that there is no retirement allowance system and this is not only true in Japan but in every other country in the world. Referring to the question of making alterations in the present commission contract ... they [the disputing employees] entirely disregard the broad principles of the various clauses in the contract based on which our business has been maintained so successfully for so many years.

The occasional abuses of the system by particular managers "cannot be taken as reasons for condemning the whole system and the Singer service contract now in force must stand in its entirety if the Company is to continue the present system of business in Japan." 60

These claims ring hollow and are puzzling in view of the company's willingness to compromise earlier and elsewhere. In Japan, in March 1925, Singer had settled one dispute by promising employees to seriously "consider" a system of retirement and severance pay. In Russia, in 1906-08, Singer's managers demonstrated what Carstensen calls "structural flexibility and procedural adjustment" in the face of perceived employee resentment by changing strictures applied to guarantors, the fidelity insurance system, and rules of the employment contract. Alfred Flohr, the successful German general manager of the Russian operation expressed determination to "develop the business to as great an extent ... as possible," even if this meant adjusting Singer's famed system. When the company faced occasional strikes by its sellers in Warsaw between 1905 and 1909, Flohr acknowledged what Carstensen describes as "serious inequities in the structure of commissions" and agreed to make changes in commissions and office procedures. ${ }^{61}$

\footnotetext{
${ }^{59}$ Kōmyō na jikyūsen," [A Strange War of Endurance], Yomiuri shinbun, 27 Oct. 1932, evening edition, 2.

60 "Statement" submitted to "T. Taketomi, in charge of Foreign Trade, Foreign Office, Kasumigaseki, Tokyo," 12 Nov. 1932, Gaimushō kiroku, 251 (original in English).

${ }^{61}$ Carstensen, American Enterprise in Foreign Markets, 64-65, 81.
} 
Singer managed to win its immediate battle in Japan without any such adjustments. The employee association broke down after a violent attack on the Yokohama central office put many of its leaders in jail and in the hospital. ${ }^{62}$ The employees abandoned their demands, and the company rehired some of the participants who pledged future loyalty to the company's satisfaction, but the majority of sellers and many store managers and collectors in Tokyo and Osaka quit or were fired. ${ }^{63}$

But the company lost the longer war. Shortly after the settlement, Richard McLeary, the Singer general manager for the Far East is said to have told the dispute leader, Yamamoto Tōsaku, "We're done for in Japan." 64 Indeed, Singer lost market share in the following years and failed to regain a prominent place in the Japanese market after World War II. In the home islands, Singer never restored sales to levels of the 1920 , and the sales of new domestic competitors expanded even more swiftly than Singer's declined. Yet Singer's sales in Korea, where it suffered no prolonged strike and faced little competition, rose to unprecedented levels, coming to account for more than one-third of total sales under the jurisdiction of its Japanese head office by 1936 and 1937. Singer's anemic sales in Japan proper took place despite a surge in demand for sewing machines. In these same years, domestic producers such as Mitsubishi, Pine (Janome), and Brothers emerged from their status as negligible presences before 1933 (the first year for which even rough domestic sales figures exist), to collectively exceed Singer sales in Japan by 1936, two years before wartime mobilization laws made it virtually impossible for Singer's Japanese operation to import new machines or parts for any purpose. As war intensified on the Asian continent and a clash loomed with the Americans and British, domestic producers were selling double the number of sewing machines that Singer had managed in its peak years in the 1920s. (See Table 1.)

The domestic producers like Brothers, Mitsubishi, or Pine-Janome succeeded in part, of course, by putting in place effective manufacturing operations, and they undercut Singer prices as well. ${ }^{65}$ But price was not the whole story. European and other American makers for some time had been selling machines in Japan at lower prices than Singer, without gaining even a modest market share. ${ }^{66}$ In addition, these new

\footnotetext{
${ }^{6}$ "Strikers Wreck Singer Office," Japan Advertiser 21 Jan. 1933, in Gaimushō kiroku, $818-19$.

${ }^{63}$ On fate of Tokyo employees, "Gaihi dai 723 gō," 28 Mar. 1933, Gaimushō kiroku, 96166. For Osaka, “Gaihi dai 195 gō,” 16 Mar. 1933, Gaimushō kiroku, 955-58.

${ }^{64}$ Shimazono, Dotōo koete, 159-61, recounts this possibly apocryphal episode in his hagiographic biography of Yamomoto.

${ }^{65}$ For the manufacturing story, see Kuwahara, "Shoki takokuseki kigyō," 52-54.

66 "Yōkyūsho," Gaimushō kiroku, 427, gives prices for comparable machines offered by Singer (250 yen), Husqvarna (170), Montross (140), Control (120), and the Japanese maker, Pine (95).
} 
Table 1

Household Machine Sales: Singer, Domestic Makers in Japan and Korea, 1933-1940

\begin{tabular}{lrrrrr}
\hline & \multicolumn{2}{c}{ Singer Sales } & & \multicolumn{2}{c}{ Domestic Makers } \\
\cline { 2 - 3 } \cline { 5 - 5 } Year & Japan & Korea & & Japan Sales & Exports (Korea) \\
& & & & 5,000 & - \\
1933 & 13,820 & 8,742 & & 12,000 & - \\
1934 & 24,259 & 16,810 & & 12,301 & - \\
1935 & 31,085 & 22,628 & & 40,924 & 3,720 \\
1936 & 34,014 & 25,246 & & 53,133 & 7,240 \\
1937 & 40,694 & 8,106 & & 104,204 & 6,069 \\
1938 & 13,024 & 2,824 & & 132,997 & 10,810 \\
1939 & 4,450 & 370 & 154,402 & 11,201 \\
1940 & 971 & &
\end{tabular}

Source: Singer, "World Results" and Janome mishin sōgyō 5o nenshi (1961), 809.

firms won the day by creatively adapting the Singer system to the local environment. They benefited as well from good fortune, as a shift to Western dress among women accelerated in the 1930 .

Pine Sewing Machine, with its trademark Janome machines (this later became the company name), was the competitor most loudly and proudly willing to make adjustments to the Singer system, even as it cloned Singer machines and adopted its sales practice. It advertised its products as "the same as the Singer model 15" but "half the price." It set up a selling network of shops, which relied on canvassers using customer cards to divide territory into blocks, that was identical to Singer's. In what the company's in-house historian called a "dark" legacy of "Singer's punitive thinking," Janome also made shop managers completely responsible for covering losses incurred through default on installment sales. ${ }^{67}$ But Pine-Janome made one major change in the compensation structure, clearly a response to the sentiments voiced by disputing Singer salesmen, when it moved from straight commission to a system of fixed pay plus commission. Despite some internal objections that guaranteed pay would invite salesmen to slack off by removing incentives, in the mid-1930s the company began to pay salesmen in Tokyo, Yokohama, and Osaka fixed monthly wages of fifteen yen, and paid those elsewhere a wage of ten yen, plus commission.

Pine drew its salesmen from "a cadre of 'converts' from Singer," as

\footnotetext{
${ }^{67}$ Janome mishin shashi hensan iinkai, ed., Janome mishin sōgyō 50 nenshi (Tokyo,
} 1961), 243 . 
well as from "those who had lost their jobs in the depression or had seen their small businesses fail." 68 The company worked hard to train this sales force, requiring employees to read a detailed manual titled (in English on the cover) "Our Salesmanship." ${ }^{69}$ Janome sales rose steadily from six thousand machines in 1937 to about nine thousand in 1938 and fourteen thousand in $1939 .{ }^{70}$

Like Singer, Janome made the majority of these sales through installment plans, but the company introduced an innovation to Singer's installment system. Along with the nationalistic leaders of other domestic producers, Pine's first president, Ose Yosaku, believed Singer had alienated potential buyers and developed a reputation as arrogant because of stringent credit requirements and a tendency to avoid lowerincome buyers. Ose set his sights on what he called the "plebian class" with a modified installment plan that he believed fit "the Japanese situation." Pine first offered this layaway-installment scheme, which it called "monthly reservation payments," in December 1930. Customers who could not afford a down payment could "reserve" their machines by paying five yen a month for six months before taking possession. By that time, Pine had its down payment in hand, and the customer had three choices: pay the remaining cost in cash; convert the balance to ordinary installment payments with interest; or continue the layaway at a discount against the cash price without taking the machine home until fully paid, in effect earning "interest" on the money deposited with Pine over the course of two years.

Such plans were not unique to Japan. In the United States, Ford and Chevrolet had offered them in the early $1920 s .{ }^{71}$ But it was significant that Pine described its "reservation payments" as an adaptation of traditional Japanese collective mutual aid, known as kō or mujin, which had earlier in the century been the inspiration for the Japan Real Estate Bank's loan system. Janome's president Ose claimed that this bank's loan plan gave him the idea for his innovation..$^{72}$ Whether Ose also knew of the American precedents is, for us, beside the point: by describing his payment plan as uniquely "Japanese," he gave it a powerful appeal in the nationalistic context of the times. The Pine-Janome managers understood and presented its selling system as better suited than Singer's to the expectations and incomes of Japanese sellers and customers alike.

\footnotetext{
${ }^{68}$ Janome mishin sōgyō 50 nenshi (1961), 243-54.

${ }^{69}$ Ibid., 246.

${ }^{70}$ Ibid., 277.

${ }^{71}$ Caldor, Financing the American Dream, 195-99.

${ }^{72}$ On rural credit societies in the 1930s, see John Embree, Suyemura: A Japanese Village (Chicago, 1939), 138-47. On Ose's view of this link, Janome mishin sōgyō 5o nen shi, x.
} 


\section{The Westernization of Dress and the Takeoff of the Sewing Machine}

In 1860, a sewing machine entered an ordinary Japanese home for the first time. It was a present to his mother by John Manjirō, the famed castaway who found his way to Massachusetts in the 1840 s and later played a role as cultural interpreter, mediating the early relations of the United States and Japan. ${ }^{73}$ Manjirō's mother is said to have greeted his gift with disappointment, not pleasure, when she discovered that the tight stitching of the machine was poorly suited to the sewing of a $\mathrm{ki}$ mono, whose outer piece and inner lining had to be loosely stitched so it could be taken apart to be cleaned and then re-sewn. ${ }^{74}$ In questioning the fit between the sewing machine and her accustomed dress, Manjirō's mother was among the first people in Japan to argue that Japan's material culture was an impediment to the spread of the sewing machine.

Over the next century, a vigorous debate took place over the suitability of sewing machines for the stitching of what came to be called wafuku (literally, Japanese clothes), a neologism that inscribed in Japanese culture a sharp contrast to a second new coinage, yôfuku (literally, overseas clothes, or Western clothes). An accompanying new lexical divide came to separate Japanese and Western modes of sewing (wasai and yōsai).

This divide was in part a cultural construction reflecting the anxious search among Japanese people since the Meiji era to define and defend a realm of "Japaneseness" in all manner of endeavor, from philosophy to sewing, but this is not to deny the real material challenge of fabricating or repairing wafuku wear with a sewing machine. Whatever the causal dynamics, Japanese users came to see Western dress, Western sewing, and the sewing machine as tightly connected. Thus, the magazine columnist of 1920 cited above praised installment payments for making it easy to buy a sewing machine, in turn to enable the shift to more "efficient" Western dress for children.

Singer resisted this association, arguing strenuously that its machine was useful for Japanese as well as Western dress. A 1910 ad in Women's World dubbed the Singer Sewing Machine of "dual use for Western and Japanese sewing." Eight years later, in an "explanation of sewing machine use" accompanying an exhibit of a Singer machine at the "Ministry of Education Exposition of Household Sciences," the company claimed:

\footnotetext{
${ }^{73}$ Christopher Benfey, The Great Wave: Gilded Age Misfits, Japanese Eccentrics, and the Opening of Old Japan (New York, 2003), ch. 1, narrates Manjirō's tale.

${ }^{74}$ Ibid., 39-40, cites the diary of Francis Hall, who recorded a conversation with Manjirō to this effect in July 1860.
} 
In sewing Japanese dress with a machine, as shown in the attached illustration, one can produce a stitch that can be taken apart with the same ease as a hand stitch, provided one practices using threads of appropriate type, with the upper and lower threads different in strength and size, and one uses stitches of proper length and looseness, and needles of appropriate size. What requires particular attention to enable unstitching as in traditional hand sewing is to carefully distinguish the upper and lower thread, and practice to make sure that the lower thread is pulled with proper tension and practice drawing [the fabric] with the left hand. If one does so, the result is far superior to hand sewing. ${ }^{75}$

It is no surprise that Singer sought to position its product as "superior to hand sewing," even for wafuku. Home sewing at the time was devoted primarily to fabrication of women's or children's clothes. Westernstyle children's dress, especially in cities and among the middle or upper classes most likely to purchase a home sewing machine, was increasingly common in these years, but most adult women continued to wear Japanese-style clothing, which-as recognized in the company's explanation-had to be sewn with a loose stitch that could be unstitched in order to be laundered.

The tortuous complexity of Singer's explanation suggests the difficulty-indeed the impossibility-of convincing customers or students that they could in fact easily use the sewing machine for Japanese dress. Even Singer's allies in the effort to promote machine sewing of wafuku, like the author of an article in the March 1919 Woman's World who sought to overturn the "misconception" that one cannot stitch Japanese dress with a sewing machine, could claim only that "ten percent of all Japanese dressmaking is done on sewing machines." 76 Singer continued to make its case, nonetheless. A panel in an elaborate brochure from the early 1920s showed an elegant silk kimono embroidered with a Singer machine and displayed in the recent "1922 Tokyo Exhibition."77 But such claims had little impact. The preference of Japanese women for wafuku constituted a significant and continuing bottleneck to the spread of sewing machines.

It was the good fortune of Japanese sewing-machine producers that this bottleneck began to break in the 1930s, just as they had established

\footnotetext{
${ }^{75}$ Shingaa saihō in, "Monbusho kaji kagaku tenrankai shuppin, saihō mishin ni kansuru setsumei sho" [Explanation of Sewing Machine Use, for Ministry of Education Exposition of Household Sciences], 30 Oct. 1918. Gakuji kankei kenmei mokuroku (Tokyo-fu, Tokyo-shi). Held at Tokyo Metropolitan Public Records Office.

76 “Jōhin na mishin shishū: fujin ni susumetaki fukugyō" [Elegant Machine Embroidery: Sidejobs Recommended for Women], Fujin Sekai 14 (Feb. 1919): 129-31.

77 "Shingaa mishin katarogu," held in collection of Edo-Tokyo Museum, item \#91222542, undated.
} 
a manufacturing capability at relatively low prices. This transformation in the habits of city-dwelling women in particular was enthusiastically documented in social surveys by the era's self-styled "modernologists" of Japanese daily life. ${ }^{78}$ Their ethnography showed that from a negligible presence of at most 2 percent strolling city streets in the mid-1920s, women wearing Western dress in public ranged from a significant minority in winter to a clear majority in the hot summers by the late 1930s. ${ }^{79}$ Demand or desire for this dress dramatically expanded both sewing-school enrollments and the market for sewing machines. Well before Singer's virtual ouster from Japan in 1938, those who more often met this demand were domestic producers with an effectively adapted version of the Singer selling system, which offered a compensation plan better aligned to the expectations of salesmen and a variant on the credit plan to attract customers spurned by Singer.

\section{Conclusion}

Singer's global sales (units sold) peaked in 1913, although even in the 1950 s the company still dominated markets in most of the world. ${ }^{80}$ In this context, Singer's 1930 decline in the Japanese market was one portentous episode in a long, slow loss of global hegemony. The company made a determined, but ultimately futile, effort to regain its place in Japan after World War II. In the 1950s, Singer began manufacturing its machines in Japan, eliminating the labor-cost advantage of local producers, but it priced the machines at a premium and never won more than a 15 percent share of the Japanese market. By 1957, 1 million out of 1.6 million sewing machines imported into the United States were made in Japan and, as Fortune put it in a lead story in 1959, "mighty Singer" was struggling to defend itself in the face of "the really alarming competition ... of some 300 Japanese companies." Japan had become the world's leading producer of household sewing machines. ${ }^{81}$ It would be an exaggeration to call the successful local adaptations of these competitors the sole factors explaining this relative shift in sewingmachine fortunes, but they were certainly part of the story.

Victoria de Grazia's magisterial recent work of trans-Atlantic history signals in the book's title a view that American capitalism, especially

\footnotetext{
${ }^{78}$ On "modernologists," see Miriam Silverberg, Erotic Grotesque Nonsense: The Mass Culture of Japanese Modern Times (Berkeley, 2006).

${ }^{79}$ Nakayama Chiyo, Nihon Fujin yōsō shi (Tokyo, 1987), 397-98, 414-15.

${ }^{80}$ On Singer sales worldwide, see Godley. On its 1950s position, Gilbert Burck, "Mighty Singer's New Competition," Fortune (Feb. 1959).

${ }^{81}$ Nihon mishin kyōkai, ed., Nihon mishin sangyō shi (Tokyo, 1961), 1-5. Burck, "Mighty Singer's New Competition," 106.
} 
the ethos and practice of mass merchandising and branding, constituted an "irresistible empire." 82 I see the weight of her argument running counter to Appadurai's stress on indigenization as adaptation, although de Grazia takes care to note and to analyze the considerable "rancor, incomprehension, and clash" in European reactions to the spread of this consumerist empire. Certainly, at a high level of generalization, but not one so high as to be meaningless, it is correct to understand as irresistible the American "advance through Europe" (and beyond), in which the Singer sales system played an important early role. But this study of Singer in Japan extends de Grazia's view in two ways: It shows a transpacific dialectic in operation more or less simultaneous to her transatlantic one. And it suggests that those on the receiving end of this globalizing process in Japan from an early time both challenged and modified (and in the postwar era re-exported) the American way of selling.

${ }^{82}$ Victoria de Grazia, Irresistible Empire: America's Advance through Twentieth Century Europe (Cambridge, Mass., 2005). 


\section{Contributors}

Michael French is professor of economic and social history at the University of Glasgow. He has published on American and British business history, particularly topics relating to the U.S. tire industry and, with Jim Phillips, to food regulation in Britain. He is currently researching salesmen in Britain and white-collar incomes from the 1880 os to the 1930 .

Andrew Gordon is the Lee and Juliet Folger Fund Professor of History at Harvard University. He has written on the history of labor and management in Japan and is currently writing a book on the impact of the sewing machine on modern Japanese business, society and culture. Recent publications include A Modern History of Japan (2nd edition, 2008) and "From Singer to Shinpan: Consumer Credit in Modern Japan," in Sheldon Garon and Patricia L. Maclachlan, eds., The Ambivalent Consumer: Questioning Consumption in East Asia and the West (2006).

Howell J. Harris is professor of history at Durham University in England. His research and publications have centered on U.S. industrial relations, most recently with the article "Between Convergence and Exceptionalism: Americans and the British Model of Labor Relations, c.1867-1920" in Labor History (2007). Recently, he launched a comprehensive study of the stove trade, which he commenced with the publication of "Conquering Winter: U.S. Consumers and the Cast-Iron Stove" in Building Research and Information (2008).

Andrew Popp is senior lecturer in business history at the University of Liverpool Management School. He has published on British business history, particularly on the history of the North Staffordshire potteries and other English industrial districts. He is currently researching the history of commercial travelers in Britain.

Roman Rossfeld is Wissenschaftlicher assistent at the Forschungsstelle für Sozial- und Wirtschaftsgeschichte (Research Unit for Social and Economic History) at the University of Zurich in Switzerland. He is the author of Schweizer Schokolade: Industrielle Produktion und kulturelle Konstruktion eines nationalen Symbols (2007). Together with Tobias Straumann he edited Der vergessene Wirtschaftskrieg: Schweizer Unternehmen im Ersten Weltkrieg (2008). His research interests are the 